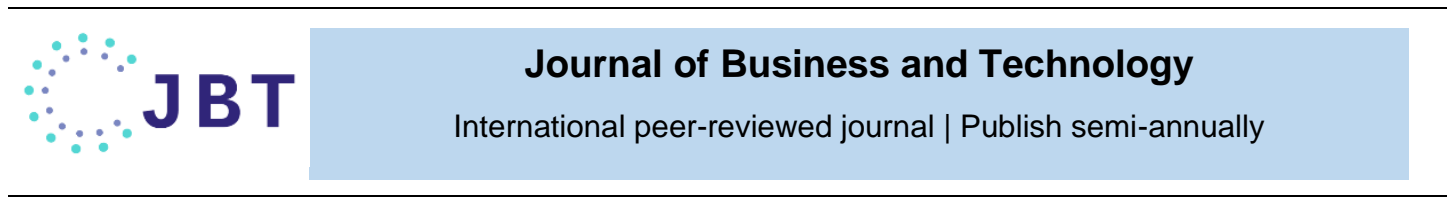

\title{
The Impact of Sustainability Reporting on Firms' Financial Performance
}

\author{
M.S. Thayaraj ${ }^{1 *}$ and W.V.A.D. Karunarathne ${ }^{2}$ \\ ${ }^{1}$ Department of Commerce, Eastern University, Sri Lanka. \\ ${ }^{2}$ Department of Accountancy, University of Kelaniya, Sri Lanka. \\ * Corresponding Author: thayarajs@esn.ac.lk
}

\begin{abstract}
This research investigates the impact of Sustainability Reporting on Firms' Financial Performance: Special Reference to the Listed Companies in the Colombo Stock Exchange in Sri Lanka. The study evaluates the impact of economic, environmental, and social disclosures as the sustainability reporting on the firm's financial performance, including Listed Companies in Sri Lanka. It was able to identify the level of disclosures on sustainability performance is lower than the expectation and compare foreign listed entities. As the sustainability disclosure is not a mandatory part to be provided in annual reports and voluntarily disclosing the performances are very low. Thus, 102 listed companies with Sustainability reporting of selected for the analysis purpose from 138 listed companies. All these companies follow the Global Reporting Initiative (GRI) G4 guidelines. This study considers secondary data collected from the annual reports, both from the Financial and Non-Financial reporting. The descriptive analysis, correlation tests, and regression analysis have conducted for analyzing purposes. The findings show a moderate positive relationship between the sustainability reporting, including economic, environmental, and social disclosures and ROA on financial performance. Thus, the consideration either on sustainability performance or on financial performance a company can achieve a moderate positive vibe of the year.
\end{abstract}

Keywords: Economic disclosures, Environmental disclosures, Financial performance, Social disclosures, Sustainability reporting.

\section{INTRODUCTION}

First and foremost, the achievement of every company to be the most earning and to be with a powerful financial background. Because the financial performance of every company becomes the sign of them. that will indicate the overall business performance. It leads the interest of investors to be high. Investors from all over the world will try to find out the performance of the companies. For the investors, return on their investments is highly valuable, and the company with high financial performance will bring all the aspects of the investors in the long term. Furthermore, the financial profitability of a firm will boost the income of employees, bring better quality and diversified products, will have a better place in environment-friendly products. Hence, based on their activities, they tend to impact the environment and society through this constant interaction with their environment (Uwuigbe et al., 2018).

A sustainability report is an organizational report that gives information about economic, environmental, social, and governance performance. Sustainability reporting is an extension of Corporate Social Reporting (CSR) to include the environmental and economic dimensions instead of only social responsibility disclosures. "It provides comprehensive sustainability details of a company, and CSR now includes matters such as climatic change, warming and animal rights, conservation of biodiversity and human rights as well as social equity. The interest of investors in company's non- 
financial performance has grown significantly over the past few years" (Ernst \& Young, 2009)

The profitable business is not enduring as a complete standing for economic growth. The awareness of corporate environmental performance (CEP) is growing as an invaluable information tool for global resources (Gnanaweera \& Kunori, 2018). Sustainability reporting is an advantageous tender to provide information about the organization's environmental initiation and environmental information. Not only the financial information include the Sustainability Reporting but also nonfinancial information considering the reporting practice. Nugroho, (2014) consisting of social activities and environmental information that emphasize more on the principles and standards of disclosure that can reflect the company's overall activity level as a whole to enable the company to grow continuously (sustainable performance).

Consequently, the progressive companies to enlighten about their economic, social, and environmental information in sustainability reporting increasingly become a trend and all Company stakeholders (Chariri and Firman, 2009). The companies disclose in Sri Lanka, and the Sustainability Report is published mostly as part of the annual report. However, the scholar's studies are concern with the sustainability reporting regarding the Disclosers facts. Rajeshwaran \& Ranjani, (2015); Dissanayake, Tilt, \& Xydias-Lobo, (2016); Dalgleish et al., (2007). It indicates that there is a gap between sustainability reporting and Firms Financial performance. However, many studies conduct developing countries unless in Sri Lanka. Therefore, this lack of knowledge has led to the conduct of the study.

Marina Grahovar (2012) find that some firms misuse the term "economic, environmental, and social disclosures" to satisfy the shareholders; the organizations provide only good information regarding the economic, environmental, and social activities which enhance their reputation. In the Sri Lankan context, The Institute of Chartered
Accountants of Sri Lanka (ICASL), Issued the Code of Best Practice on Corporate Governance 2017. Even though Investors and other stakeholders can assess sufficient information on how ESG risks and opportunities are recognized, managed, measured, and reported in the company's annual report.

"There is incomplete literature and an ongoing debate on the issue of performance of firms. There is wider gap specifically in the case of growing economics" (Mirza and Javed,2013) like Sri Lanka because most of the research done based on the data from developed economics. At the same time, Sustainability performance varies considerably in their way of performance largely due to their voluntary nature and the lack of an accountability framework in reporting the sustainability performance. Thus, companies are free to choose from the guidelines in any way they prefer, which contributes to assessing the performance. Therefore, this topic on sustainability performance in the Sri Lankan context receives relatively less attention in research than in other parts of the world.

It is questionable that the difference in reporting practices due to lack of proper reporting regulations criticize the stakeholders for depending solely on the information provided by the companies for making decisions. Therefore, the research problem of this study can be identified as follows: "What is the Impact of Sustainability Reporting on Firms' Financial Performance in Sri Lanka?"

The following research questions are elevated based on the research problem, according to the study. What is the current level of Sustainability Reporting Disclosure? What is Sustainability Reporting's impact on the Financial Performance of listed companies in Sri Lanka? The Study's primary objective is to identify the current level of Sustainability Reporting Disclosure and Financial Performance of listed companies in Sri Lanka. Furthermore, to assess the impact of Sustainability Reporting on the Financial performance of the listed companies in Sri Lanka. 


\section{LITERATURE REVIEW}

Today's market is highly competitive with unprecedented pressure for the successes and sustains for their successful future. Corporations are being pressured by shareholders and investors and other stakeholders such as customers, creditors, suppliers, society and community, and the environmental anteroom. According to Reddy \& Gordon, (2010), it is related to numerous contemporary business and reporting practices, including corporate social responsibility (CSR), CS, corporate citizenship, integrated reporting, and sustainable entrepreneurship. The terms "Sustainability" or "Sustainability Reporting" is not having a single meaning, even though it is a vast area when revising the literature.

The historical evaluation of sustainability reporting focuses on developing sustainability, and related reporting evident several shifts (Fifka, 2012; Kolk, 2010). In earlier studies mostly referred to in the 1970 s and 1980s, studies mostly referred to social reporting, and environmental reporting was at the centre of attention in the 1990s (Swarnapali, 2017). In the millennium era, the terms then predominantly shifted to the analysis of Corporate Sustainable Reporting (CSR) or sustainability reporting (Fifka, 2012). Then the development of the voluntary standard-setting by the Global Reporting Initiatives (GRI) (Kolk, 2010). There are different stages of development to reflect CS and CSR adoption. In the First stage, firms began engaging in window dressing activities by changing the wording to reflect CSR language without substance (Aras \& Crowther, 2009), The second stage called cost containment, whereby firms re-engineer the business process to reduce consumptions of water and energy that reduce costs and improve financial performance. Stakeholder engagement is the third stage, whereby firms start being concerned by employee and customer satisfaction. The fourth stage consists of communicating about these initiatives by developing CSR reports. The fifth stage is sustainability, which would imply radical changes to business practice and a significant re-engineering process (Swarnapali, 2017). CS concept addresses and captures the most important alarms of the public regarding business and society relationships, and it has a bright future.

As per Zhang et al. (2003), social auditing is a vigorous process consisting of planning, accounting, auditing and reporting, embedding, and stakeholder engagement followed by an organization to account for its sustainability performance and improve its sustainability performance. Companies' performances towards sustainability in a balanced and holistic manner will position them to innovate and compete in the rapidly changing and resource-constrained global economy. It is no longer enough for companies to perform towards society or the environment in isolation. Comprehensive sustainability strategies are expected from companies because various survey reports (Hughes, G. 2013; KPMG, 2008, 2013) indicate a theoretical relationship between CS reporting and firms' performance.

The profitability of a company measured by ROA and ROE indicators affects CSR disclosure. The results of this study support the results of the studies conducted by Yuniasih et al. (2007), and the research conducted by Soelistyoningrum and Prastiwi (2011) showed that Sustainability Report disclosure had significant effects on ROA in a positive direction. The results were consistent with a previous study conducted by Dahlia and Siregar (2008). Also, as an accountingbased measurement, ROA gauges the operating and financial performance of the firm (Klapper \& Love, 2002). The measurement is such that the higher the ROA, the effect is the use of assets to the advantage of shareholders (Haniffa \& Huduib, 2006). Higher ROA also reflects the company's effective use of its assets in serving the economic interests of its shareholders (Ibrahim \& AbdulSamad, 2011).

\section{Institutional Theory}

Institutional theory is an approach to understanding organizations and management practices as social rather than economic pressures. It has become a popular perspective within management theory because of its ability to explain organizational behaviours that defy economic rationality (Eric H, 2013). 
The explanation, according to institutional theory, is based on the key idea that the adoption and retention of many organizational practices are often more dependent on social pressures for conformity and legitimacy than on technical pressures for economic performance (Eric H, 2013).

\section{Legitimacy Theory}

Legitimacy theory is essential to meet the societal norms and expectations to ensure the firm's survival in the long term. The definition of this theory is "a condition which exists when an entity's value system is in harmony with the value system of society." (Lindblom, 1993). The proponents of legitimacy theory argue that sustainability reporting tends to reduce the risk of regulatory actions and boycotts by stakeholders, and it strengthens the firm's license to operate (Patten, 1992); (Deegan, 2000). "it is probable that legitimacy theory is the most widely used theory to explain environmental and social disclosures" (Campbell, Craven, \& Shrives, 2003) while, according to Gray, Kouhy, \& Lavers, (1995), legitimacy theory has an advantage over other theories in that it provides disclosing strategies that organizations may adopt to legitimate their existence that may be empirically tested.

\section{Stakeholder Theory}

Stakeholders refer to those individuals, groups, or organizations that are likely to influence or be influenced by the operations and decisions of the firm. According to Freeman, (1984), the stakeholder theory upholds that firms have accountability towards a broad range of stakeholders, apart from shareholders, i.e. creditors, customers, suppliers, employees, government, community, environment, and future generations. King (2002) recognized the significance of integrated sustainability reporting in strengthening the relationship between a firm and society in which it operates. Ignoring the stakeholder interests may taint the firm's public image, which would unfavourably affect its financial performance. Elijido-Ten, (2006) defined as "Basic proposition of stakeholder theory is that the firm's success is dependent upon the successful management of the relationships that a firm has with its stakeholders". The firm's target is to be maximizing profit and shareholder wealth.

\section{Agency Theory}

The agency theory said the relationship which exists between the owners and managers is based on principal-agent. This theory has gained significance in the wake of corporate governance scandals like the Satyam scam. It is well known that conflict of interest and information asymmetry exists between company managers (insiders) and shareholders \& other stakeholders (outsiders). De Klerk \& de Villiers, (2012) said, in the absence of adequate public disclosure by companies, the amount of risk perceived by investors rises significantly. It causes the market to undervalue the shares or demand more returns from firms that do not disclose appropriately. Sustainability Reporting reduces information asymmetry and risk perceived by investors, increases market efficiency, and reduces the cost of capital to the firm (Dhaliwal et al., 2011; Warren \& Thomsen, 2012).

Sri Lanka like a developing country, although increasing the importance of the reporting practices of sustainability. In terms of sustainability reporting in Sri Lanka evolved over the last decade, with chambers of commerce and professional accounting bodies championing the cause through awards programs that recognize best in class performance providing the motivation required to stimulate activity (she-consults, 2018). The GRI Guidelines for social and environmental reporting are voluntarily adopting and encouraging by more corporates in Sri Lanka. Consequently, the Failure of companies to upload their Sustainability Reports to the GRI database deters research on the subject besides portraying a lower level of reporting than the actual level (sheconsults, 2018).

Several studies are conducting the Financial Performance and Sustainability and different ways to analyze this relationship. There are different results on each study, and they are sorted into three types of impact: positive, neutral, and negative (Hong Yuh, Fábio, \& Thiago, 2017). Kapoor and Sandhu (2010) 
ISSN 2738-2028 (Online) | Vol. 5 | No. 2 | 2021 July

analyze the annual reports and websites of Indian companies regarding the impact of sustainability in corporate financial performance (CFP). The study was conducted in 75 companies representing 14 industries to identify the current social responsibility reporting framework. GRI guidelines were used in this study and found a low level of disclosures in sustainability components, including; governance, economy, environment, and society in Sri Lankan companies (Wijesinghe, 2012). The scholar found that the Return on sales (ROS), Return on asset (ROA), and Return on equity (ROE) have a significant impact on sustainability, and it shows a positive link between corporate financial performance and sustainability.

Moreover, Pan et al. (2014) concluded that sustainability, even though it appears to have no significant impact on the growth rate or expansion rate of net assets, may positively impact a firm's profits. Overall, the authors found that sustainability had significant effects on ROA, ROE, and Earnings per Share EPS. The 250 observation is acceptable theoretically as much previous research has used less observation than this (Bhattacharyya, 2014).

The indicators of economic activities, social activities and environmental activities of CSR have significant negative impact on Tobin's Q. However, the CSR have not been practiced by larger number of companies in Sri Lanka (Kengatharan et al., 2020). Dissanayake, et al., (2016) examined the relationship between sustainability reporting/sustainability key performance indicator (KPI) reporting and company-specific characteristics namely; company size, company age and financial performance using annual reports, sustainability reports and website contents of sixty public listed companies in Sri Lanka and found that company size as the most significant factor that effect on sustainability KPIs). In contrast to Wijesinghe (2012) largescale corporations disclosed high level of disclosures to exploit performance benefits. The commitments towards implementing voluntary reporting practices in a developing country like Sri Lanka can be influenced by the absence of a fixed model, recognized listing platform and the cost (De Silva P O
2019). Low numbers of researchers have focused on this area in Sri Lankan contest. The findings of the Thilakasiri, (2012) identified different organizations used different methods to disclose their CSR activities, although they had all adopted international CSR standards and principles to practice them. Wijesinghe (2012) conducted a study in 75 companies which represent 14 industries to identify the current social responsibility reporting framework. GRI guidelines were used in this study and found a low level of disclosures in sustainability components including; governance, economy, environment, and society in Sri Lankan companies.

However, there is literature lacking in the Sri Lankan context. Therefore, the study contributing to the literature to fill the gap by performing content analysis and considering the potential relationship between sustainability disclosures and the firms' financial performance in Sri Lanka.

Hypotheses formed based on research questions and research objectives to investigate the relationship between sustainability reporting and a firm's financial performance. To answer the research questions of this study, the following hypothesis is formulated based on the literature review:

H1: There is a significant relationship between sustainability reporting and the Financial Performance of Listed Companies in the CSE.

\section{RESEARCH METHODS}

\section{Target Population, Sample, and Sampling Technique}

The population of this study consisted of all listed companies in CSE during 2018/2019. Sekaran (2000) defined the sample as a subset of the population in question and consisted of selecting members from the particular population. This study selects 102 listed companies randomly from 20 sectors. The proportionate stratified random sampling method is applied to select the 102 listed companies as the sample for the study. According to Alvi (2016), the stratum's proportionate stratified random sample size is 
ISSN 2738-2028 (Online) | Vol. 5 | No. 2 | 2021 July

defined proportionally to the number of elements present in the stratum. Figure 1 shows the sample of 102 companies calculated at the 95\% confidence level and $5 \%$ confidence interval from the total population of 138 companies disclosed in the sustainability report in the annual report. The following equation is applied for sample selection (Surveysystem, 2021)

$$
\begin{aligned}
& \text { Sample } \\
& =\frac{\text { Each selected sector }}{\text { Population (138) }} \mathrm{X} \text { Total Sample (102) }
\end{aligned}
$$

Determine Sample Size

Confidence Level: $\quad$ O95\% O99\%

Confidence Interval: $5 \%$

Population: 138

Calculate

Clear

Sample size needed: 102

Figure 1: Sample size

\section{Method of Data Collection}

This study is based on secondary data collected from the annual report published by the CSE for 2018/2019. The reason for selecting these companies is that these companies' financial statements are compulsorily audited by recognized audit companies. Secondary data were collected through paper-based sources as well as from electronic-based sources and research journals and articles. Some of these sources are Emerald articles and journals, books on sales and marketing. Further, the information on financial performance is also collected through financial statements in the companies' annual reports. The G4 frame work and GRI contents were gathered from the annual reports. The data and information required for this study collected from the annual reports in Colombo stock exchange (CSE) websites by referring to annual financial reports.

The concept of sustainable measure is indicated with Economic measures, Environmental measures, and Social measures. Return indicates the concept of financial performance on Asset. The impact indicators will be measured by perceived responses of various sustainability reports. The return on assets will be measured by the calculation of the ratio using annual reports of companies. The control variable is to be the firm size.

This research then focuses on disclosing items in the Company's sustainability reporting that are examined based on the GRI-G4 index. Based on GRI 2016, standard disclosure and performance indicators are used to indicate sustainability categories. According to that, there are 13 economic disclosures, 30 environmental disclosures, and 40 social disclosures criteria were designed for performance measurement based on requirements from the modification of GRI. Since Sri Lanka still lacks in a few areas of sustainability.

\section{Measurement of Variables}

The conceptual model developed and supports the existence of a causal relationship between sustainability reporting and financial performance. Sustainability Reporting and its impact on Firms Financial Performance have emerged as important areas for research in recent years.

Empirical studies have used different measures of financial performance (FP) to link CSR and FP. Indeed, Griffin and Mahon, based on 51 studies, identified 80 financial measures of corporate performance. Amongst them, return on sales (ROS), Return on Equity (ROE), and return on assets (ROA)or marketbased measures, such as market value to book value and price to earnings ratio and market return, have been used widely. While the latter predicts long-term, the former captures short-term financial performance. In line with these studies, the present study adopted Return on Assets (ROA); return on Equity (ROE); return on Sales (ROS).

The dependent variable used as a measure of company performance is the return on assets (ROA). Return on asset is one of the profitability ratios which measures the income or operating success of a company for a given period (Weygandt, 2007, p. 793). ROA computes as; 


$$
\text { ROA }=\frac{\text { Net profit }}{\text { Total Assets }}
$$$$
\text { ISSN 2738-2028 (Online) | Vol. } 5 \text { | No. } 2 \text { | } 2021 \text { July }
$$

Some of the indicators are merged with related indicators. Clarkson et al. (2008) Toms, (2002) and Van Staden \& Hooks (2007) developed a 5-point scale to assess the quality of disclosure, this quality scale as the following,

\section{Scale Description \\ $0 \quad$ No disclosure \\ 1 Specific endeavor in non- quantitative terms \\ 2 Quantified performance data \\ 3 Quantified performance data relative to benchmarks \\ 4 Quantified performance data at the disaggregated level}

The control variable used as a measure of firm size is total assets (TA). This control variable, which has been included and examined in prior research, is firm size. Firm size is used as a control variable in many studies relating to CSP and firm performance (Lo, S. F., \& Sheu, H. J., 2007; Hussain, 2015; King and Lenox, 1998). Therefore firm size is identified as the control variables of the study.

This research proposes the models of the independent variable is sustainability performance disclosures. Sustainability reports involve disclosure on a company's sustainability performance viewed from three aspects; they are economic, environmental, and social disclosures.

GRI Sustainability Guidelines on Economic, Environmental, and Social Performance is the most prominent current reporting guideline (Morhardt et al. 2002). Research conducted by Dincer (2011) also suggests adopting the GRI format as a CSR reporting model to be used by the firm for disclosing information.

\section{DATA ANALYSIS}

Data analysis is done by using statistical techniques to evaluate individual characteristics of variables, assessing the status of variables, relationship, and impact of variables which are mentioned as objectives of the study. For this study, the techniques used to analyze the data generated are Descriptive Statistics, Regression, and Correlation. It is consistent with the work of Chtourou et al. (2001). Pearson correlation coefficient is the most commonly used coefficient. It is the method that measures both the degree (strength) of association and direction of variables. Moreover, the Statistical Package for Social Sciences Version 22 (SPSS 22) is used to analyze the data.

The model used the multiple regression method. The equation is presented below:

$\mathrm{Y}=\mathrm{a}+\mathrm{b}_{1} \mathrm{X}_{1}+\mathrm{b}_{2} \mathrm{X}_{2}+\mathrm{b}_{3} \mathrm{X}_{3}+\mathrm{b}_{4} \mathrm{X}_{4}+\mathrm{e}$

where:

$\mathrm{Y}=\mathrm{ROA}$ (Return on Assets)

$\mathrm{a}=$ constant

$\mathrm{b}_{1-3}=$ regression coefficient

$\mathrm{X}_{1}=$ Economic disclosure

$\mathrm{X}_{2}=$ Environmental disclosure

$\mathrm{X}_{3}=$ Social disclosure

$\mathrm{X}_{4}=$ Firm Size

\section{FINDINGS AND DISCUSSION}

The data analysis to study the application of sustainable measures in Sri Lankan listed firms, Univariate analysis (descriptive statistic), Bivariate (correlation), and multivariate test have been adopted using the SPSS (22.0) computer package. Data presentation has been done by using tables and charts.

\section{Data Presentation}

\section{Descriptive Analysis of Economical Disclosure}

To find out the average level of economical disclosure among sample firms, the researcher analyzed the economical disclosure practices by using descriptive statistics of the mean and standard deviation of economical disclosure of firms.

As shown in above Table 1, the overall mean value of economical disclosure among sample firms is 0.82 , and it can be varied by 0.57 . Based on the mean value of economical disclosure, economical disclosure among sample firms is low level. 
Table 1: Mean and Standard Deviation of Economical Disclosure

\begin{tabular}{lccc}
\hline \multicolumn{1}{c}{ Economical Disclosure items } & Mean & S.D. & SEM \\
\hline Economical Disclosure indicators & 0.82 & 0.57 & 0.06 \\
Economic performance & 1.35 & 0.63 & 0.06 \\
Market presence & 0.70 & 0.73 & 0.07 \\
Indirect economic impacts & 0.64 & 0.85 & 0.08 \\
Procurement practices & 0.64 & 0.98 & 0.10 \\
Anti-corruption & 0.48 & 0.68 & 0.07 \\
Anti-competitive behavior & 0.56 & 0.89 & 0.09 \\
\hline
\end{tabular}

Source: Sample Survey

When considering the dimension of economical disclosure, it is found that mean value for economic performance (1.35), market presence $(0.70)$, indirect economic impacts (0.64), procurement practices (0.64), anti-corruption (0.48), and anti-competitive behavior (0.56) shows low level among sample firms.

Table 2: Overall No of Companies Level of Economical Disclosure

\begin{tabular}{clcc}
\hline Range & \multicolumn{1}{c}{ Level } & $\begin{array}{c}\text { No of } \\
\text { Companies }\end{array}$ & Percentage \\
\hline $\mathbf{0 . 0} \leq \mathbf{X i} \leq \mathbf{1 . 5}$ & Low level & $\mathbf{8 9}$ & $\mathbf{8 7 . 2 \%}$ \\
$\mathbf{1 . 5}<\mathrm{Xi} \leq \mathbf{2 . 5}$ & Moderate level & $\mathbf{1 1}$ & $\mathbf{1 0 . 8 \%}$ \\
$\mathbf{2 . 5}<\mathrm{Xi} \leq \mathbf{4 . 0}$ & High level & $\mathbf{2}$ & $\mathbf{2 \%}$ \\
& Total & 102 & $100 \%$ \\
\hline
\end{tabular}

Source: Sample Survey

Table 2 specifies the frequency level of economical disclosure. Accordingly, It is noted that among sample firms about $87.2 \%$ of firms have a low level of economical disclosure, $10.8 \%$ of firms have a moderate level of economical disclosure and $2 \%$ of firms have a high level of disclosure.

\section{Table 3: Mean and Standard Deviation of Environmental Disclosure}

\section{Descriptive Analysis of Environmental Disclosure}

To find out the average level of environmental disclosure among sample firms, the researcher analyzed the environmental disclosure practices by using the descriptive statistic of the mean and standard deviation of environmental disclosure of firms.

\begin{tabular}{lccc}
\hline \multicolumn{1}{c}{ Environmental Disclosure Items } & Mean & S.D & SEM \\
\hline Environmental Disclosure Indicators & 0.57 & 0.27 & 0.03 \\
Materials & 0.89 & 0.48 & 0.05 \\
Energy & 0.76 & 0.48 & 0.05 \\
Water and effluents & 0.59 & 0.67 & 0.07 \\
Biodiversity & 0.24 & 0.35 & 0.03 \\
Emissions & 0.52 & 0.35 & 0.03 \\
Effluents and waste & 0.64 & 0.51 & 0.05 \\
Environmental compliance & 0.63 & 0.69 & 0.07 \\
Supplier environmental assessment & 0.29 & 0.50 & 0.05
\end{tabular}

Source: Sample Survey

$\mathbf{5 8} \mid \mathrm{P}$ a g e 
ISSN 2738-2028 (Online) | Vol. 5 | No. 2 | 2021 July

As shown in above Table 3, the overall mean value of environmental disclosure among sample firms is 0.57 , and it can be varied by 0.27. Based on the mean value of environmental disclosure, environmental disclosure among sample firms is low level. When considering the dimension of environmental disclosure, it is found that mean value for materials (0.89), energy $(0.76)$, water and effluents $(0.59)$, biodiversity (0.24), emissions (0.52), effluents and waste (0.64), environmental compliance (0.63) and supplier environmental assessment (0.29) shows low level among sample firms.

Table 4: Overall No of Companies Level of Environmental Disclosure

\begin{tabular}{clcc}
\hline Range & \multicolumn{1}{c}{ Level } & No of Companies & Percentage \\
\hline $\mathbf{0 . 0} \leq \mathbf{X i} \leq \mathbf{1 . 5}$ & Low level & 101 & $99 \%$ \\
$\mathbf{1 . 5}<\mathbf{X i} \leq \mathbf{2 . 5}$ & Moderate level & 1 & $1 \%$ \\
$\mathbf{2 . 5}<\mathbf{X i} \leq \mathbf{4 . 0}$ & High level & Nil & Nil \\
& Total & $\mathbf{1 0 2}$ & $\mathbf{1 0 0 \%}$ \\
\hline
\end{tabular}

Source: Sample Survey

Table 4 specifies the frequency level of environmental disclosure. Accordingly, it is noted that among sample firms, about $99 \%$ of firms have a low level of environmental disclosure, and $1 \%$ of the firm has a moderate level of environmental disclosure.

\section{Descriptive Analysis of Social Disclosure}

To find out the average level of social disclosure among sample firms, the researcher analyzed the social disclosure practices by using the descriptive statistic of the mean and standard deviation of social disclosure of firms.

\section{Table 5: Mean and Standard Deviation of Social Disclosures}

\begin{tabular}{lccc}
\hline \multicolumn{1}{c}{ Social Disclosure items } & Mean & S.D. & SEM \\
\hline Social Disclosure indicators & 0.65 & 0.29 & 0.03 \\
Employment & 1.40 & 0.56 & 0.06 \\
Labor management relations & 0.50 & 0.66 & 0.06 \\
Occupational health and safety & 0.35 & 0.34 & 0.03 \\
Training and education & 1.59 & 0.56 & 0.06 \\
Diversity and equal opportunity & 0.82 & 0.67 & 0.07 \\
Non discrimination & 0.70 & 0.78 & 0.08 \\
Freedom of association and collective bargaining & 0.45 & 0.61 & 0.06 \\
Child labor & 0.51 & 0.66 & 0.06 \\
Forced or compulsory labor & 0.60 & 0.69 & 0.07 \\
Security practices & 0.33 & 0.57 & 0.06 \\
Rights of indigenous peoples & 0.19 & 0.44 & 0.04 \\
Human rights assessment & 0.26 & 0.39 & 0.04 \\
Local communities & 0.86 & 0.55 & 0.05 \\
Supplier social assessment & 0.52 & 0.54 & 0.05 \\
Public policy & 0.27 & 0.49 & 0.05 \\
Customer health and safety & 0.66 & 0.60 & 0.06 \\
Marketing and labeling & 0.66 & 0.67 & 0.07 \\
Customer privacy & 0.62 & 0.73 & 0.07 \\
Socioeconomic compliance & 0.81 & 0.78 & 0.08 \\
\hline Source Sample Survey & & &
\end{tabular}

Source: Sample Survey 
ISSN 2738-2028 (Online) | Vol. 5 | No. 2 | 2021 July

As shown in above Table 5, the overall mean value of social disclosure among sample firms is 0.65 , and it can be varied by 0.29 . Based on the mean value of social disclosure, social disclosure among sample firms is low level. When considering the dimension of social disclosure, it is found that mean value for employment (1.04), labor-management relations (0.50), occupational health and safety (0.35), diversity and equal opportunity (0.82), non-discrimination (0.70), freedom of association and collective bargaining (0.45), child labor (0.51), forced or compulsory labor $(0.60)$, security practices $(0.33)$, rights of indigenous peoples (0.19), human rights assessment (0.26), local communities (0.86), supplier social assessment (0.52), public policy $(0.27)$, customer health and safety (0.66), marketing and labeling (0.66), customer privacy $(0.62)$ and socioeconomic compliance (0.81) shows low level while the mean value for training and education (1.59) indicates moderate level among sample firms.

Table 6: Overall No of Companies Level of Social Disclosure

\begin{tabular}{clcc}
\hline Range & \multicolumn{1}{c}{ Level } & No of Companies & Percentage \\
\hline $\mathbf{0 . 0} \leq \mathbf{X i} \leq \mathbf{1 . 5}$ & Low level & 101 & $99 \%$ \\
$\mathbf{1 . 5}<\mathbf{X i} \leq \mathbf{2 . 5}$ & Moderate level & 1 & $1 \%$ \\
$\mathbf{2 . 5}<\mathbf{X i} \leq \mathbf{4 . 0}$ & High level & Nil & Nil \\
& Total & $\mathbf{1 0 2}$ & $\mathbf{1 0 0 \%}$ \\
\hline
\end{tabular}

Source: Sample Survey

Table 6 specifies the frequency level of social disclosure. Accordingly, it is noted that among sample firms, about $99 \%$ of firms have a low level of social disclosure, and $1 \%$ of the firm has a moderate level of social disclosure.

\section{Correlation Analysis}

Bivariate Pearson Correlation produces a sample correlation coefficient, $r$, which measures the strength and direction of the

Table 7: Degree of Correlation

linear relationship between pairs of continuous variables by extension; The Pearson Correlation evaluates whether there is statistical evidence for a linear relationship among the same pairs of variables in the population. The Pearson correlation is a paramedic measure. The r-value indicates the strength and direction of the correlation. The following table 7 shows the degree of correlation is using for the analysis.

\begin{tabular}{|c|c|c|c|c|c|c|c|c|c|c|c|}
\hline $\begin{array}{c}\text { Degree of } \\
\text { Correlation }\end{array}$ & Perfect & & Strong & & & oder & & & Weak & & Zero \\
\hline $\begin{array}{l}\text { Positive } \\
\text { Correlation }\end{array}$ & 1 & 0.9 & 0.8 & 0.7 & 0.6 & 0.5 & 0.4 & 0.3 & 0.2 & 0.1 & 0 \\
\hline $\begin{array}{l}\text { Negative } \\
\text { Correlation }\end{array}$ & -1 & -0.9 & -0.8 & -0.7 & -0.6 & -0.5 & -0.4 & -0.3 & -0.2 & -0.1 & 0 \\
\hline
\end{tabular}

Source: Sample Survey

\section{Correlation Between Economical Disclosure and ROA}

Table 8: Correlation between Economical Disclosure and ROA

\begin{tabular}{llcc}
\hline & & Economical Disclosure & Return on Assets \\
\hline Economical & Pearson Correlation & 1 & $.512^{* *}$ \\
Disclosure & Sig. (2-tailed) & & .000 \\
& $\mathrm{~N}$ & 102 & 102 \\
\hline
\end{tabular}

**. Correlation is significant at the 0.01 level (2-tailed).

Source: Sample Survey

60|P a g e 
ISSN 2738-2028 (Online) | Vol. 5 | No. 2 | 2021 July

The coefficient of correlation ( $r$ ) is less than 0.5 , and it can be identified as a moderate positive relationship $(\mathrm{r}=0.512, \mathrm{p}>0.05)$ between Economical Disclosure and ROA.

\section{Correlation between Environmental Disclosure and ROA}

Table 9: Correlation between Environmental Disclosure and ROA

\begin{tabular}{llcc}
\hline & & Environmental Disclosure & Return on Assets \\
\hline \multirow{2}{*}{ Environmental } & Pearson Correlation & 1 & $.462^{* *}$ \\
Disclosure & Sig. (2-tailed) & & .000 \\
& $\mathrm{~N}$ & 102 & 102 \\
\hline
\end{tabular}

**. Correlation is significant at the 0.01 level (2-tailed).

Source: Sample Survey

The coefficient of correlation ( $\mathrm{r}$ ) is less than between Environmental Disclosure and 0.5 , and it can be identified as a moderate ROA.

positive relationship $(\mathrm{r}=0.462, \mathrm{p}>0.05)$

Correlation Between Social Disclosure and ROA

Table 10: Correlation between Social Disclosure and ROA

\begin{tabular}{llcc}
\hline & & Social Disclosure & Return on Assets \\
\hline \multirow{3}{*}{ Social Disclosure } & Pearson Correlation & 1 & $.633^{* *}$ \\
& Sig. (2-tailed) & & .000 \\
& $\mathrm{~N}$ & 102 & 102 \\
\hline
\end{tabular}

**. Correlation is significant at the 0.01 level (2-tailed).

Source: Sample Survey

The coefficient of correlation ( $r$ ) is less than 0.5 , and it can be identified as moderate positive $(r=0.633, p>0.05)$ between Social Disclosure and ROA.

\section{Multiple Regression Analysis}

The multiple regression analysis is used to determine the functional relationship between the dependent variable and independent variable for predictions and making other inferences. Further, the normality test for regression analysis based on figure 2, we can see that the existing points always follow and approach the diagonal line. Thus, it can be concluded that the residual value is normally distributed so that the regression analysis procedure has been fulfilled.

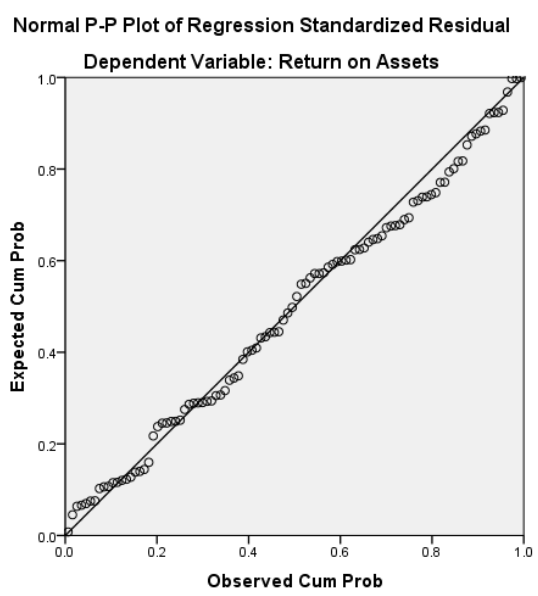

Figure 2: Normal P-P Plot of Regression Standardized Residual of Dependent Variable 
Table 11: Model Summary

\begin{tabular}{lllll}
\hline Model & R & R Square & Adjusted R Square & $\begin{array}{l}\text { Std. Error of the } \\
\text { Estimate }\end{array}$ \\
\hline 1 & $.728^{\mathrm{a}}$ & .530 & .511 & .0466599 \\
\hline
\end{tabular}

a. Predictors: (Constant), Firm Size, Environmental Disclosure, Social Disclosure, Economic Disclosure

Source: Sample Survey

The bivariate correlation of coefficient $(\mathrm{R})$ is 0.728 is indicates a strong positive relationship between Economical, Environmental, Social Disclosures, and ROA. Determination of coefficient $\left(\mathrm{R}^{2}\right)$ is 0.530 indicate that for the sample $53 \%$ of the variation of the dependent variable (ROA) can be explained by the independent variable (Economic, Environmental, Social Disclosures)

Adjusted $\mathrm{R}^{2} 51.1 \%$ indicates that it is an adjustment of the $\mathrm{R}$ Square that penalizes the addition of extraneous predictors to the model. The adjusted $\mathrm{R}^{2}$ smaller than $\mathrm{R}^{2}$ statistic because it downward adjusts the $\mathrm{R}^{2}$ statistics when additional variables of limited significance are added to a model. If it's adjusted $\mathrm{R}^{2}$ statistic is high when one regression model fits the data better than another regression model.

Table 12: ANOVA Table

\begin{tabular}{lllllll}
\hline Model & & Sum of Squares & df & Mean Square & F & Sig. \\
\hline \multirow{4}{*}{1} & Regression & .239 & 4 & .060 & 27.390 & $.000^{\mathrm{b}}$ \\
& Residual & .211 & 97 & .002 & & \\
& Total & .450 & 101 & & & \\
\hline
\end{tabular}

a. Dependent Variable: Return on Assets

b. Predictors: (Constant), Firm Size, Environmental Disclosure, Social Disclosure, Economic Disclosure

Source: Sample Survey

According to the table, the regression sum of squares is the variation explained by the 0.000 , and the regression model is a good fit regression. The significance of the model is for the data.

Table 13: Coefficients

\begin{tabular}{|c|c|c|c|c|c|c|}
\hline \multirow{2}{*}{\multicolumn{2}{|c|}{ Model }} & \multicolumn{2}{|c|}{$\begin{array}{l}\text { Unstandardized } \\
\text { Coefficients }\end{array}$} & \multirow{2}{*}{$\begin{array}{c}\text { Standardized } \\
\text { Coefficients } \\
\text { Beta } \\
\end{array}$} & \multirow[t]{2}{*}{$\mathbf{t}$} & \multirow[t]{2}{*}{ Sig. } \\
\hline & & B & Std. Error & & & \\
\hline \multirow{5}{*}{1} & (Constant) & .048 & .066 & & .730 & .467 \\
\hline & $\begin{array}{l}\text { Economic } \\
\text { Disclosure }\end{array}$ & .021 & .010 & .180 & 2.135 & .035 \\
\hline & $\begin{array}{l}\text { Environmental } \\
\text { Disclosure }\end{array}$ & .058 & .020 & .232 & 2.913 & .004 \\
\hline & Social Disclosure & .114 & .018 & .499 & 6.388 & .000 \\
\hline & Firm Size & -.006 & .003 & -.143 & -2.038 & .044 \\
\hline
\end{tabular}

a. Dependent Variable: Return on Assets

Source: Sample Survey

62|P a g e 
ISSN 2738-2028 (Online) | Vol. 5 | No. 2 | 2021 July

The table illustrated constant statistic is 0.048 units show that the model would predict if all of the three independent variables were Zero. The $\beta$ coefficient for Economic Disclosure is 0.021 . This result explains that on average, if Economical Disclosure increases, ROA will increase by 0.021 units. The $\beta$ coefficient for Environmental Disclosure is 0.058. This result explains that on average, if Environmental Disclosure increases, ROA will improve by 0.058 units. The $\beta$ coefficient for Social Disclosure is 0.114 . This result explains that on average, if Social Disclosure increase, ROA will increase by 0.114 units.

Based on the table, the equation for the regression line is,

$R O A=0.048+0.021(E C O)+0.058(E N V)$

$+0.114($ SOC $)-0.006($ Fsize $)+e$

H1: There is a significant relationship between sustainability reporting and the Financial Performance of Listed Companies in the CSE.

The sustainability reporting has an impact on the financial performance of companies in Sri Lanka. The economic, environmental, and social sustainability reporting positively impacts companies' financial performance in Sri Lanka, especially ROA. Therefore, the study accepts the hypothesis because the Pvalue is less than 0.05 coefficient value is positive.

Further, the disclosure of economics, environmental, social disclosures, and firm size has a significant impact on the company's financial performance. The pvalue less the 0.05 that the disclosure of each aspect of economic, environmental, and social disclosures and the firm size of the company will increase the firm's financial performance in the future.

\section{Discussion on Descriptive Statistics}

\section{Level of Economic Disclosures}

Economic disclosures are the independent variable of this study. It consists of six dimensions which are economic performance, market presence, indirect economic impacts, procurement practices, anti-corruption, and anti-competitive behavior. Indicators of economic performance are direct economic value generated and distributed, financial implications and other risks and opportunities due to climate change, defined benefit plan obligations, and other retirement plans and financial assistance received from the government with a mean value of $1.86,1.65$, 1.26 and 0.61 respectively with the standard deviation of $0.75,0.95,1.17$ and 0.88 correspondingly and overall mean value of economic performance is 1.35 which is deviated from 0.63 . This indicated that economic performance indicates a low level among selected Sri Lankan firms.

Indicators of market presence are ratios of standard entry level wage by gender compared to local minimum wage and proportion of senior management hired from the local community with the mean value of 0.39 and 1.00 respectively with the standard deviation of 0.76 and 1.11 correspondingly and overall mean value of market presence is 0.70 which is deviated from 0.73 . This indicated that the market presence indicates a low level among selected Sri Lankan firms.

Indicators of indirect economic impacts are the development of infrastructure and service supported and significant indirect economic impacts with the mean value of 0.79 and 0.49 respectively with the standard deviation of 1.10 and 0.83 correspondingly and overall mean value of indirect economic impacts is 0.64 which is deviated from 0.85 . This indicated that the indirect economic impacts display at a low level among selected Sri Lankan firms.

Indicators of procurement practices are the proportion of spending on local suppliers with a mean value of 0.64 with a standard deviation of 0.98 . So, the mean value of procurement practices is 0.64 which is deviated from 0.98 . This indicated that the procurement practices display at a low level among selected Sri Lankan firms.

Indicators of anti-corruption are operations assessed for risks related to corruption, communication and training on anti- 
corruption policies and procedures and confirmed incidents of corruption and actions are taken with a mean value of $0.39,0.43$, and 0.62 respectively with the standard deviation of $0.79,0.83$, and 0.92 correspondingly and overall mean value of anti-corruption is 0.48 which is deviated from 0.68 . This indicated that the anti-corruption displays at a low level among selected Sri Lankan firms.

Indicators of anti-competitive behavior are legal action for anti-competitive behavior, anti-trust and monopoly practices with a mean value of 0.56 with the standard deviation of 0.89 . So, the mean value of anti-competitive behavior is 0.56 which is deviated from 0.89 . This indicated that anti-competitive behavior displays at a low level among selected Sri Lankan firms.

\section{Level of Environmental Disclosures}

Environmental disclosures are the independent variable of this study. It consists of eight dimensions which are materials, energy, water and effluents, biodiversity, emissions, effluents and waste, environmental compliance, and supplier environmental assessment. Indicators of materials are materials used by weight or volume, recycled input materials used, and reclaimed products and their packaging materials with a mean value of $0.40,1.22$, and 1.06 respectively with the standard deviation of $0.76,0.78$, and 0.78 correspondingly and overall mean value of materials is 0.89 which is deviated from 0.48 . This indicated that the materials indicate at a low level among selected Sri Lankan firms.

Indicators of energy are energy consumption within the organization, energy consumption outside of the organization, energy intensity, reduction of energy consumption, and reductions in energy requirements of products and services with the mean value of 1.32 , $0.79,0.64,0.64$, and 0.39 respectively with the standard deviation of $0.75,0.81,0.81$, $0.81,0.78$ and 0.58 correspondingly and overall mean value of energy is 0.76 which is deviated from 0.48 . This indicated that energy indicates a low level among selected Sri Lankan firms.

Indicators of water and effluents are water withdrawal, water discharge, and water consumption with the mean value of 0.64 , 0.63 , and 0.50 respectively with the standard deviation of $0.77, \quad 0.77$, and 0.74 correspondingly, an overall mean value of water and effluents is 0.59 which is deviated from 0.67. This indicated that water and effluents indicate at a low level among selected Sri Lankan firms.

Indicators of biodiversity are operational sites owned, leased, managed in, or adjacent to, protected areas and areas of high biodiversity value outside protected areas, significant impacts of activities, products, and services on biodiversity, habitats protected or restored, and IUCN Red List species and national conservation list species with habitats in areas affected by operations with the mean value of $0.28,0.22,0.26$ and 0.21 respectively with the standard deviation of $0.57,0.50,0.44$ and 0.41 correspondingly and overall mean value of biodiversity is 0.24 which is deviated from 0.35 . This indicated that biodiversity indicates at a low level among selected Sri Lankan firms.

Indicators of emissions are direct (Scope 1) GHG emissions, energy indirect (Scope 2) GHG emissions, other indirect (Scope 3) GHG emissions, GHG emissions intensity, reduction of GHG emissions, emissions of ozone-depleting substances (ODS) and nitrogen oxides (NOX), sulfur oxides (SOX), and other significant air emissions with the mean value of $0.98,0.59,0.57,0.42,0.25$, 0.34 and 0.48 respectively with the standard deviation of $0.74,0.75,0.71,0.60,0.50,0.50$ and 0.66 correspondingly and overall mean value of emissions is 0.52 which is deviated from 0.35. This indicated that emissions indicate at a low level among selected Sri Lankan firms.

Indicators of effluents and waste are water discharge by quality and destination, waste by type and disposal method, significant spills, transport of hazardous waste, and water bodies affected by water discharges and/or runoff with the mean value of $0.66,0.79$, $0.57,0.53$ and 0.64 respectively with the standard deviation of $0.75,0.83,0.73,0.70$ and 0.70 correspondingly and overall mean value of effluents and waste is 0.64 which is deviated from 0.51 . This indicated that 
effluents and waste indicate at a low level among selected Sri Lankan firms.

Indicators of environmental compliance are non-compliance with environmental laws and regulations with a mean value of 0.63 with a standard deviation of 0.69 . So, the mean value of environmental compliance is 0.63 which is deviated from 0.69. This indicated that environmental compliance displays at a low level among selected Sri Lankan firms.

Indicators of supplier environmental assessment are new suppliers that were screened using environmental criteria and negative environmental impacts in the supply chain and actions taken with the mean value of 0.28 and 0.29 respectively with the standard deviation of 0.60 and 0.59 correspondingly and overall mean value of supplier environmental assessment is 0.29 which is deviated from 0.50 . This indicated that supplier environmental assessment indicates at a low level among selected Sri Lankan firms.

\section{Level of Social Disclosures}

It consists of social disclosure has nineteen dimensions which are employment, labormanagement relations, occupational health and safety, training and education, diversity and equal opportunity, non-discrimination, freedom of association and collective bargaining, child labor, forced or compulsory labor, security practices, rights of indigenous peoples, human rights assessment, local communities, supplier social assessment, public policy, customer health and safety, marketing and labeling, customer privacy and socioeconomic compliance. Indicators of employment are new employee hires and employee turnover, benefits provided to fulltime employees that are not provided to temporary or part-time employees, and parental leave with a mean value of $1.65,1.65$, and 0.91 respectively with the standard deviation of $0.71, \quad 0.77$, and 0.95 correspondingly and overall mean value of employment is 1.40 which is deviated from 0.56. This indicated that the employment indicates at a low level among selected Sri Lankan firms.
Indicators of labor-management relations are minimum notice periods regarding operational changes with a mean value of 0.50 with a standard deviation of 0.66 . So, the mean value of labor-management relations is 0.50 which is deviated from 0.66 . This indicated that labor-management relations display at a low level among selected Sri Lankan firms.

Indicators of occupational health and safety are occupational health and safety management system, hazard identification, risk assessment, and incident investigation, occupational health services, worker participation, consultation, and communication on occupational health and safety, worker training on occupational health and safety, promotion of worker health, prevention and mitigation of occupational health and safety impacts directly linked by business relationships, workers covered by an occupational health and safety management system, work-related injuries and workrelated ill health with the mean value of 0.38 , $0.67,0.30,0.34,0.25,0.22,0.25,0.53,0.45$ and 0.16 respectively with the standard deviation of $0.65,0.84,0.54,0.57,0.43,0.44$, $0.73,0.73$ and 0.39 correspondingly and overall mean value of occupational health and safety is 0.35 which is deviated from 0.34 . This indicated that occupational health and safety indicates at a low level among selected Sri Lankan firms.

Indicators of training and education are average hours of training per year per employee, programs for upgrading employee skills and transition assistance programs, and percentage of employees receiving regular performance and career development reviews with the mean value of $1.66,1.72$, and 1.41 respectively with the standard deviation of $0.67,0.57$ and 0.81 correspondingly and overall mean value of training and education is 1.59 which is deviated from 0.56 . This indicated that training and education indicate at a moderate level among selected Sri Lankan firms.

Indicators of diversity and equal opportunity are the diversity of governance bodies and employees and ratio of basic salary and remuneration of women to men with the mean 
value of 1.02 and 0.63 respectively with the standard deviation of 0.86 and 0.81 correspondingly and overall mean value of diversity and equal opportunity is 0.82 which is deviated from 0.67. This indicated that diversity and equal opportunity indicates at a low level among selected Sri Lankan firms.

Indicators of non-discrimination are incidents of discrimination and corrective actions taken with a mean value of 0.70 with a standard deviation of 0.78 . So, the mean value of nondiscrimination is 0.70 which is deviated from 0.78 . This indicated that non-discrimination displays at a low level among selected Sri Lankan firms.

Indicators of freedom of association and collective bargaining are operations and suppliers in which the right to freedom of association and collective bargaining may be at risk with a mean value of 0.45 with the standard deviation of 0.61 . So, the mean value of freedom of association and collective bargaining is 0.45 which is deviated from 0.61. This indicated that freedom of association and collective bargaining displays at a low level among selected Sri Lankan firms.

Indicators of child labor are operations and suppliers at significant risk for incidents of child labor with a mean value of 0.51 with a standard deviation of 0.66 . So, the mean value of child labor is 0.51 which is deviated from 0.66 . This indicated that child labor displays at a low level among selected Sri Lankan firms.

Indicators of forced or compulsory labor are operations and suppliers at significant risk for incidents of forced or compulsory labor with a mean value of 0.60 with a standard deviation of 0.69 . So, the mean value of forced or compulsory labor is 0.60 which is deviated from 0.69. This indicated that forced or compulsory labor displays at a low level among selected Sri Lankan firms.

Indicators of security practices are security personnel trained in human rights policies or procedures with a mean value of 0.33 with a standard deviation of 0.57 . So, the mean value of security practices is 0.33 which is deviated from 0.57 . This indicated that security practices display at a low level among selected Sri Lankan firms.

Indicators of rights of indigenous peoples are incidents of violations involving rights of indigenous peoples with a mean value of 0.19 with a standard deviation of 0.44 . So, the mean value of rights of indigenous peoples is 0.19 which is deviated from 0.44 . This indicated that the rights of indigenous peoples display at a low level among selected Sri Lankan firms.

Indicators of human rights assessment are operations that have been subject to human rights reviews or impact assessments, employee training on human rights policies or procedures and significant investment agreements and contracts that include human rights clauses or that underwent human rights screening with the mean value of $0.22,0.28$ and 0.29 respectively with the standard deviation of $0.44,0.48$ and 0.48 correspondingly and overall mean value of human rights assessment is 0.26 which is deviated from 0.39 . This indicated that human rights assessment indicates at a moderate level among selected Sri Lankan firms.

Indicators of local communities are operations with local community engagement, impact assessments and development programs and operations with significant actual and potential negative impacts on local communities with the mean value of 1.14 and 0.59 respectively with the standard deviation of 0.72 and 0.65 correspondingly and overall mean value of local communities is 0.86 which is deviated from 0.55. This indicated that local communities indicate at a low level among selected Sri Lankan firms.

Indicators of supplier social assessment are new suppliers that were screened using social criteria and negative social impacts in the supply chain and actions taken with the mean value of 0.60 and 0.44 respectively with the standard deviation of 0.66 and 0.59 correspondingly and overall mean value of supplier social assessment is 0.52 which is deviated from 0.54 . This indicated that supplier social assessment indicates a low level among selected Sri Lankan firms. 
Indicators of public policy are political contributions with a mean value of 0.27 with a standard deviation of 0.49 . So, the mean value of the public policy is 0.27 which is deviated from 0.49 . This indicated that public policy displays at a low level among selected Sri Lankan firms.

Indicators of customer health and safety are an assessment of the health and safety impacts of product and service categories and incidents of non-compliance concerning the health and safety impacts of products and services with the mean value of 0.54 and 0.77 respectively with the standard deviation of 0.62 and 0.82 correspondingly and overall mean value of customer health and safety is 0.66 which is deviated from 0.60 . This indicated that customer health and safety indicate at a low level among selected Sri Lankan firms.

Indicators of marketing and labeling are requirements for product and service information and labeling, incidents of noncompliance concerning product and service information and labeling, and incidents of non-compliance concerning marketing communications with the mean value of 0.54 , 0.70 , and 0.75 respectively with the standard deviation of $0.66,0.81$ and 0.84 correspondingly and overall mean value of marketing and labeling is 0.66 which is deviated from 0.67 . This indicated that marketing and labeling and safety indicates a low level among selected Sri Lankan firms.

Indicators of customer privacy are substantiated complaints concerning breaches of customer privacy and losses of customer data with a mean value of 0.62 with a standard deviation of 0.73 . So, the mean value of customer privacy is 0.62 which is deviated from 0.73. This indicated that customer privacy displays at a low level among selected Sri Lankan firms.

Indicators of socioeconomic compliance are non-compliance with laws and regulations in the social and economic area with a mean value of 0.81 with a standard deviation of 0.78 . So, the mean value of socioeconomic compliance is 0.81 which is deviated from 0.78. This indicated that socioeconomic compliance displays at a low level among selected Sri Lankan firms.

\section{Discussion on Correlation Analysis}

This study was conducted to examine and obtain empirical evidence about the impact of sustainability reporting on a firm's financial performance of the companies. The results obtained from regression analysis and correlation matrix show mixed results; the overall sustainability disclosures are positively impacted by the firm's financial performance.

The Economical Disclosure and ROA show a strong positive relationship with $\mathrm{r}=0.512$. Further, the Medium positive relationship of the Environmental Disclosure and ROA with $r=0.462$ and the $r=0.633$ indicates the moderate positive relationship between Social Disclosure and ROA.

\section{Discussion on Multiple Regression Analysis}

The bivariate correlation of coefficient $(\mathrm{R})$ is 0.728. It is indicating a moderate positive relationship between sustainable reporting (economic disclosures, environmental disclosures, and social disclosures, and firm size) and financial performance in listed companies.

Determinants of coefficient $\left(\mathrm{R}^{2}\right)$ is 0.530 indicates that for the sample 53\% of the variation of the dependent variable of financial performance can be explained by the independent variables of sustainable reporting (economic disclosures, environmental disclosures, social disclosures, and firm size).

Based on Table 13, the regression equation can be written as follows:

$Y=0.048+0.021 X_{1}+0.058 X_{2}+0.114 X_{3}-$ $0.006 X_{4}+e$

Where

$$
\begin{aligned}
& Y \text { - Financial Performance } \\
& X_{1} \text { - Economic Disclosures } \\
& X_{2} \text { - Environmental Disclosures } \\
& X_{2} \text { - Social Disclosures } \\
& X_{4}-\text { Firm Size }
\end{aligned}
$$


The $\mathrm{B}$ coefficient for economic disclosures is 0.021 , which means that when economic disclosures are increased by one unit, financial performance will increase by 0.021 units. It also indicates that the B coefficient for environmental disclosures is 0.058 , which means that when environmental disclosures are increased by one unit, financial performance will increase by 0.058 . It also indicates that the $\mathrm{B}$ coefficient for social disclosures is 0.114 , which means that when social disclosures are increased by one unit, financial performance will increase by 0.114 .

According to regression analysis, economic disclosure, environmental disclosures, and social disclosures positively impact financial performance in listed companies. Furthermore, the previous studies found the environmental performance indicators depicted mixed results depicted a mere positive correlation, and regression was significant (Gnanaweera \& Kunori, 2018). The study was conducted to examine and obtain empirical evidence about the effects of Sustainability Report disclosure on the financial performance of companies that include ROA, CR, DER, IT, and DPR. (Nugroho \& Arjowo, 2014). Which showed any indication of the positive direction of the outcomes of the SR disclosure levels, which means more SR disclosure, the higher profitability values. The impact of sustainability on profitability tends to be stronger than the reciprocal influence generated from profitability; thus, this may imply an influence that varies following time. A sustainability-driven policy exists among the higher performers' group. (Chang \& Regina Kuo, 2008). An author such as Relatore \& Laureando (2014) argued in support of the Score variables by category are positively correlated with ROA. It means that they could be significant in the panel regression, displaying and explaining a sort of positive impact on this corporate financial performance indicator. The research was designed to find the environmental disclosure practice of listed companies in Sri Lanka. The Researchers found that majority of companies disclosed less information and the average disclosure rate of selected companies is at a significantly lower level. (Aruppala et al., 2013). Sustainability Reporting and Its
Impact on Financial Performance of the study confirms that there is no improvement in the level of economic, environmental, and social disclosures over the period of time. (Silva, 2019).

\section{CONCLUSIONS AND FUTURE RESEARCH DIRECTIONS}

The finding of this study contributes to a better understanding of the research objective. The study's main objective is to identify the present level of sustainability reporting and financial performance of listed companies in Sri Lanka. The result obtained from the descriptive analysis can conclude that under the variables of sustainability reporting, that are economic disclosure, environmental disclosure, and social disclosure.

Further, examining the relationship between the sustainability reporting and the financial performance of the listed companies in Sri Lanka, the result have been obtained through correlation and regression analysis to examine the relationship and impact of sustainability disclosure of economic, environmental, and social disclosure variables on Financial performance of ROA.

The first question is to find out the current level of Sustainability Reporting Disclosure of listed companies in Sri Lanka. According to the analysis done through descriptive and correlation findings, the correlation shows with the impact of Return on the Assets; it could be identified that there is a moderate positive relationship with economic disclosures, environmental disclosures, and social disclosures. The second question is to determine the impact of Sustainability Reporting on the Financial Performance of listed companies in Sri Lanka. With the analysis done to identify the performance impact, there is a moderate positive relationship between sustainable reporting of economic disclosures, environmental disclosures, and social disclosures, and firm size and financial performance in listed companies.

With the significant impact of sustainability disclosures on the Return on the Assets, it could be identified that there is a moderate positive relationship with the variable and a 
moderate positive impact. As the sustainability performance increases, the Return on Asset will also increase. Thus, it can be recommended to the listed organizations that the increment or a satisfactory level of ROA may bring an identifiable level of sustainability performance.

It is recommended that all companies have economic, environmental, and social disclosure information to increase the quality of disclosure in Sri Lanka. Hence, economic, environmental, and social disclosure is still at a low level in Sri Lanka. Because there is no parliamentary law, even the Institute of Chartered Accountants of Sri Lanka does not have any special economic, environmental, and social disclosure standards. Stockholders may face difficulty when compare and crosscheck the reports.

As per the research there is a high consideration on sustainability disclosure. This research focused how current year sustainability disclosure affects to the current year financial performance. But in long term sustainability disclosure can affect to the different way than this result. As per study most of the firms promote to do sustainability activates and disclose through publications to inform the customer even though the financial performance and sustainability disclosure.

This paper provides insinuation for future studies. Future researchers can determine roots for sustainability reporting while analyzing the disclosures over an extended period. Moreover, cross-sectional analysis across the different industries can be performed by identifying challenges encountered by the firms' in reporting economic, environmental and social performance.

Finally, the study results are very important in identifying the relationship between sustainability reporting and a firm's financial performance in Sri Lanka, which is a moderate positive relationship. However, the firms disclose the sustainability disclosures voluntarily. There is an increasing trend in sustainability disclosure and the GRI index, which is the global standard for sustainability reporting. These GRI guidelines indicate moving towards sustainability

\section{REFERENCES}

Abeywardana, N. L. E., \& Panditharathna, K. M. (2016). The Extent and Determinants of Voluntary Disclosures in Annual Reports: Evidence from Banking and Finance Companies in Sri Lanka. Accounting and Finance Research, 5(4). https://doi.org/10.5430/afr.v5n4p147

Aggarwal, P. "Impact of Sustainability Performance of Company on its Financial Performance: A Study of Listed Indian Companies". Global Journal of Management and Business Research Finance, vol. 13, pp. 61-70, 2013.

Aguinis, H., \& Glavas, A. (2012). What we know and don't know about corporate social responsibility: a review and research agenda. Journal of Management, 38(4), 932-968.

Ahlström, J., \& Ficeková, M. (2017). The relationship between current financial slack resources and future CSR performance. A quantitative study of public companies in the Nordic Markets.

Aras, G., \& Crowther, D. (2009). Corporate sustainability reporting: a study in disingenuity? Journal of Business Ethics, 5(4), 219-230.

Aruppala, M. D., Aruppala, D., \& Perera, P. (2013). Environmental Reporting Practice of Listed Companies in Sri Lanka: Evidence from Manufacturing, Motor, Power and Energy Sectors. November 2013.

Beddewela, E., \& Herzig, C. (2013). Corporate social reporting by MNCs' subsidiaries in Sri Lanka. Accounting Forum, 37(2), 135-149.

Campbell, D., Craven, B., \& Shrives, P. (2003 ). "Voluntary social reporting in three FTSE sectors: A comment on perception and legitimacy". Accounting, Auditing and Accountability Journal, 04, 558-81.

Chariri, A dan Firman A. J. 2009. "Retorika Dalam Pelaporan Corporate Social Responsibility: Analisis Semiotik Atas 
Sustainability Reporting Pt Aneka Tambang Tbk". Simposium Nasional Akuntansi XII Palembang 4-6 November 2009.

Clarkson, P.M., Li, Y., Richardson, G.D. and Vasvari, F.P. (2008) 'Revisiting the relation between environmental performance and environmental disclosure: an empirical analysis', Accounting, Organizations and Society, 33, pp. 303-327. ScienceDirect [Online]. doi:10.1016/j.aos.2007.05.003

(Accessed: 28 May 2012).

Connelly, B., Trevis Certo, S., Duane, Ireland, R., \& Reutzel, C. (2010). Journal of Management: Signaling Theory: A Review and Assessment. Retrieved 09 20, 2018, from http://journals.sagepub.com/doi/10.1177 /0149206310388419

Cormier, D., Magnan, M., \& Van Velthoven, B. (2005). Environmental disclosure quality in large German companies: economic incentives, public pressures or institutional conditions? European Accounting Review, 35(2), 157-172.

Dahlia, Lely dan Sylvia Veronica Siregar. 2008. Pengaruh Corporate Social Responsibility terhadap Kinerja Perusahaan (Studi Empiris pada Perusahaan yang Tercatat di Bursaa Efek Indonesia pada tahun 2005 dan 2006). Simposium Nasional Akuntansi XI. Pontianak.

Deegan, C. (2000). Financial Accounting Theory. Beijing: Mc Graw Hill.

Dhaliwal, D., Li, O., Tsang, A., \& Yang, Y. (2011). Voluntary nonfinancial disclosure and the cost of equity capital: The initiation of corporate social responsibility reporting. The Accounting Review, 86(1), 59-100.

Dhaliwal, D., Li, O., Tsang, A., \& Yang, Y. (2011). Voluntary nonfinancial disclosure and the cost of equity capital: The initiation of corporate social responsibility reporting. The Accounting Review, 86(1), 59-100.
Dissanayake, D., Tilt, C., \& Xydias-Lobo, M. (2016). Sustainability reporting by publicly listed companies in Sri Lanka. Journal of Cleaner Production, 129, 169182.

Elijido-Ten, E. (2006). "Extending the application of stakeholder theory to Malaysian corporate environmental disclosures"Unpublished Doctor of Philosophy Thesis, Australia: Swinburne University of Technology.

Ernst \& Young, "Detecting Financial Statement Fraud: What Every Manager Needs to Know," E \& Y LLP, London, 2009, pp. 1-8. www.ey.com

Eric H, K. (2013). Encyclopedia of Management Theory. SAGE Publications, 379-384.

Fifka, M. (2012). The development and state of research on social and environmental reporting in global comparison. Journal Für Betriebswirtschaft, 62(1), 45-84.

Freeman, R. (1984). Strategic Management: A Stakeholder Approach. London: Financial Times Prentice Hall.

Garg, P. (2015). Impact of sustainability reporting on firm performance of companies in India. International Journal of Marketing and Business Communication, 4(3), 38-45.

Gray, R., Kouhy, R., \& Lavers, S. (1995). "Constructing a research database of social and environmental reporting by UK companies". Accounting, Auditing and Accountability Journal, 08(02), 78101.

Haniffa, R. \& Hudaib, M., 2006. Corporate Governance Structure and Performance of Malaysian Listed Companies. Journal of Business Finance \& Accounting, 33, 1034-1062.

Hogan, J., \& Lodhia, S. (2011). Sustainability reporting and reputation risk management: an Australian case study. International Journal of Accounting and Information Management, 19(3), 267287. 
Hong Yuh, C., Fábio, G., \& Thiago, H. (2017). The Quality of Sustainability Reports and Corporate Financial Performance: Evidence From Brazilian Listed Companies. SAGE Open, 1-9.

Hughes, G. (2013). Carrots and sticks. Emergency Medicine Journal, 30(8), 608. https://doi.org/10.1136/emermed2013-202786

Hussain, N. (2015), "Impact of sustainability performance on financial performance: an empirical study of global fortune (N100) firms", Working Papers No. 1, Department of Management, Ca' Foscari University of Venice, Venice.

Kapoor, S., \& Sandhu, H. (2010). Does it pay to be socially responsible? An empirical examination of the impact of corporate social responsibility on financial performance. Global Business Review, 185-208.

Ibrahim, H., \& Samad, F. A. (2011). Corporate Governance Mechanisms and Performance of Public-Listed FamilyOwnership in Malaysia. International Journal of Economics and Finance, 3(1). https://doi.org/10.5539/ijef.v3n1p105

Kengatharan, L., Suganya, D. F. J., \& Sulochani, R. G. R. (2020). Corporate social responsibility and firm performance: evidence from manufacturing companies in Sri Lanka. International Journal of Accounting and Business Finance, 6(1), 42. https://doi.org/10.4038/ijabf.v6i1.50

Kerr, J., Rose, P., \& Villiers, C. (2015). Sustainability reporting integrated into management control systems. Pacific Accounting Review, 27(2), 189-207.

King, A. A., \& Lenox, M. J. (2001). Does It Really Pay to Be Green? An Empirical Study of Firm Environmental and Financial Performance: An Empirical Study of Firm Environmental and Financial Performance. Journal of Industrial Ecology, 5(1), 105-116. https://doi.org/10.1162/1088198017533 58526.
King, M. (2002). ing Report on Corporate Governance for South Africa. Institute of Directors in Southern Africa.

Klapper, L. F., \& Love, I. (2005). Corporate Governance, Investor Protection and Performance in Emerging Markets. SSRN Electronic Journal. https://doi.org/10.2139/ssrn.303979

Kolk, A. (2010). Trajectories of sustainability reporting by MNCs. Journal of World Business, 45, 367-374.

KPMG (2008), "International survey of corporate responsibility reporting", available at: www.kpmg.com/EU/en/Documents/KP MG_International_survey_Corporate_re sponsibility_Survey_Reporting_2008.pd f (accessed 10 May 2021).

KPMG (2013), "Indian corporate responsibility reporting survey", available at: www.kpmg.com/IN/en/IssuesAndInsigh ts/ArticlesPublications/Documents/India -Corporate-ResponsibilityReportingSurvey-2013.pdf (accessed 10 May 2021).

Kwaghfan, A. (2015). impact of sustainability reporting on corporate performance of selected quoted companies in Nigeria.

Laskar, N. (2018). Impact of corporate sustainability reporting on firm performance: an empirical examination in Asia, Journal of Asia Business Studies, 12(4), 571-593, https://doi.org/10.1108/JABS-11-20160157.

Lindblom, C. (1993). The Implication of Organization Legitimacy for Corporate Social Performance and Disclosure.

Lo, S. F., \& Sheu, H. J. (2007). Is corporate sustainability a value-increasing strategy for business? Corporate Governance: An International Review, 15(2), 345-358. https://doi.org/10.1111/j.14678683.2007.00565.x

Manetti, G. (2011). The quality of stakeholder engagement in sustainability reporting: empirical evidence and critical points. 
ISSN 2738-2028 (Online) | Vol. 5 | No. 2 | 2021 July

Corporate Social Responsibility and Environmental Management, 18(2), 110122.

Mirza and Javed,2013 (2013). Determinants of financial performance of a firm: Case of Pakistani stock market. Journal of Economics and International Finance, $5(2)$, $43-52$. https://doi.org/10.5897/jeif12.043

Nugroho, I. Arjowo. I.S "The Effects Of Sustainability Report Disclosure Towards Financial Performance". Internasional Journal of Business and Management Studies, vol. 03, pp. 225239, 2014.

Patten, D. (1992). Intra-industry environmental disclosures in response to the Alaskan oil spill: a note on legitimacy theory. Accounting, Organizations and Society, 17(5), pp. 471-475.

Reddy, K., \& Gordon, L. (2010). 'The effect of sustainability" Reddy, K. \& Gordon, L. W. 2010. 'The effect of sustainability reporting on financial performance: a Reddy, K. \& Gordon, L. The effect of sustainability reporting on financial performance: an empirical study using listed companies. Journal of Asia Entrepreneurship and Sustainability, 6(2), 19-42.

Reddy, K., \& Gordon, L. W. (2010). The Effect of Sustainability Reporting on Financial Performance: An Empirical Study using Listed Companies. Journal of Asia Entrepreneurship and Sustainability, 6(2), 19-42.

she-consults. $\quad(2018, \quad 10 \quad 18)$. SUSTAINABILITY REPORTING IN SRI LANKA. Retrieved from sheconsults: http://www.sheconsults.com/insights/

Silva, P. O. D. (2019). Sustainability Reporting and Its Impact on Financial Performance: A Study of the Sri Lankan Financial Sector. Vidyodaya Journal of Management, $5(1)$. https://doi.org/10.31357/vjm.v5i1.3913

Soelistyoningrum, J. N. (2011). Pengaruh Pengungkapan Sustainability Report
Terhadap Kinerja Keuangan ( Studi Empiris Pada Perusahaan Yang Terdaftar Dalam Bursa Efek Indonesia ). Diponegoro Journal of Accounting, 4345.

Surveysystem.com. 2021. Sample Size Calculator - Confidence Level, Confidence Interval, Sample Size, Population Size, Relevant Population Creative Research Systems. [online] Available at: $<$ https://www.surveysystem.com/sscalc. htm\#one> [Accessed 10 May 2021].

Swarnapali, R. (2017). Corporate sustainability: A Literature review. Journal for Accounting Researchers and Educators (JARE), 1(1).

Tasneem, F., Muhammad, S., \& Basit, A. (2016). The Impact of Environmental Reporting on Firms' Performance. International Journal of Accounting and Business Management, 4(2), 275-300.

Uwuigbe, U., Teddy, O., Uwuigbe, O. R., Emmanuel, O., Asiriuwa, O., Eyitomi, G. A., \& Taiwo, O. S. (2018). Sustainability Reporting and Firm Performance : A BiDirectional Approach. Academy of Strategic Management Journal, 17(3), 116.

Whetman, L. L. (2018). The Impact of Sustainability Reporting on Firm Profitability. Undergraduate Economic Review, 14(1), 4.10.17261-p

Wijesinghe, K. N., \& Senaratne, S. (2011). Impact of disclosure of corporate social responsibility on corporate financial performance in bank, finance and insurance sector in Sri Lanka.

Wijesinghe, K. N. (2012). Current Context of Disclosure of Corporate Social Responsibility in Sri Lanka. Procedia Economics and Finance, 2(May 2012), 171-178. https://doi.org/10.1016/s22125671(12)00077-9

Williams, B. (2015). Reporting on sustainability by Australian councils - a communication perspective. Asian Review of Accounting, 23(2), 186-203. 
ISSN 2738-2028 (Online) | Vol. 5 | No. 2 | 2021 July

Yuniasih, N. W., \& Wirakusuma, M. G. (2009). Pengaruh Kinerja Keuangan terhadap Nilai Perusahaan dengan Pengungkapan Corporate Sosial Responsibility dan Good Corporate Governance Sebagai Variabel Intervening. Universitas Udayana.Bali, $1-10$.

Zhang, J., Fraser, I. and Hill, W.Y. (2003), “A comparative study of social audit models and reports", in Andriof, J., Waddock, S., Husted, B. and Rahman, S. (Eds), Unfolding Stakeholder Thinking 2, Greenleaf Publishing, Sheffield, pp. 24466. 